\title{
KAJIAN RESEPSI SASTRA DAN NILAI-NILAI PENDIDIKAN KARAKTER DALAM NOVEL FAITH AND THE CITY KARYA HANUM SALSABIELA RAIS DAN RANGGA ALMAHENDRA
}

\author{
Septi Lisnaini, Siti Isnaniah \\ Tadris Bahasa Indonesia, Fakultas Adab dan Bahasa \\ Institut Agama Islam Negeri Surakarta \\ septilisna97@gmail.com
}

\begin{abstract}
Abstrak: "Penelitian ini memiliki tujuan yaitu mendeskripsikan resepsi pembaca novel Faith and The City karya Hanum Salsabiela Rais dan Rangga Almahendra. Penelitian ini merupakan penelitian studi pustaka dengan menggunakan pendekatan deskriptif kualitatif. Teknik pengumpulan data dalam penelitian ini adalah teknik analisis isi dokumen dan teknik wawancara. Peneliti menggunakan berbagai teknik pengumpulan data (analisis isi dokumen yang mendalam) dan menggunakan teori kajian resepsi sastra. Kemudian teknik analisis data yang digunakan adalah analisis model interaktif. Hasil penelitian ini menunjukkan resepsi pembaca novel Faith and The City karya Hanum Salsabiela Rais dan Rangga Almahendra ini memiliki persepsi yang tidak jauh berbeda, yaitu mereka sepakat bahwa novel Faith and The City merupakan novel yang yang sangat unik, menarik, dan representatif dibaca oleh semua kalangan. Banyak pembelajaran dan nilai-nilai pendidikan karakter yang positif dapat diambil pelajarannya bagi pembaca."
\end{abstract}

Kata Kunci: Novel, resepsi sastra, nilai-nilai pendidikan karakter.

\section{PENDAHULUAN}

Novel merupakan salah satu karya sastra yang memiliki sifat imajinasi dari penggambaran seorang pengarang. Novel memberikan gambaran kehidupan, yang dituliskan dalam sebuah tulisan. Jalan cerita di dalam novel seperti yang diinginkan atau diimajinasikan oleh pengarang melalui cerita yang ada di dalam karya sastra tersebut. Karya sastra berbentuk novel biasanya banyak menceritakan tentang interaksi manusia dengan manusia serta interaksi manusia dengan lingkungan sekitarnya.

Sebuah karya fiksi berbentuk novel menceritakan sebuah dunia imajinasi yang diandaikan oleh pengarang dengan kehidupan nyata manusia dan disajikan dalam sebuah tulisan. Karya sastra yang berbentuk fiksi atau biasa disebut novel memiliki komponen isi yang berupa tema, alur, karakter tokoh yang banyak, suasana dan setting cerita yang beragam. Pembaca dapat mengambil pesan atau amanat dari pengarang yang tersirat dalam novel tentang 
nilai-nilai pendidikan karakter yang baik dan dapat diambil pelajaran serta diterapkan dalam kehidupan nyata ${ }^{1}$.

Novel yang merupakan suatu karya sastra memiliki peran penting sebagai suatu kekayaan budaya bangsa Indonesia. Novel merupakan karya seni yang memiliki sifat imajinatif, indah, menyenangkan, menghibur dan dapat berguna bagi pembaca yang menikmati bacaannya. Dengan demikian novel merupakan sebuah karya sastra yang tidak dapat terpisahkan dari manusia sebagai pengarang dan manusia sebagai penikmat sastra yaitu seorang pembaca. $^{2}$

Senada dengan pendapat tersebut, peneliti mengungkapkan bahwa apresiasi karya sastra dari pembaca sebagai seorang penikmat karya sastra yang peranannya adalah penting. Salah satu bentuk apresiasi pembaca adalah dengan menilai karya sastra itu sendiri. Dalam melakukan penilaian terhadap suatu karya sastra pembaca tentu mempunyai kriteria yang memadai ketika akan melakukan penilaian terhadap suatu karya sastra yang dibacanya.

Novel merupakan salah satu jenis karya sastra yang populer dan banyak penikmatnya, dalam novel menampilkan serangkaian peristiwa secara terstruktur yang jalan cerita yang dapat menjadi sebuah pelajaran kehidupan, suatu kehidupan yang nyata dan dapat menjadi sebuah tugas untuk memberi pelajaran kepada para pembaca. Cerita yang dimiliki setiap karya sastra biasanya terkandung pesan moral di dalamnya ${ }^{3}$. Pesan moral tersebut bisanya berhubungan erat dengan kehidupan manusia yang memiliki sifat luhur, dan bermartabat. Pesan moral yang terkandung dalam cerita bisanya disampaikan oleh oleh tokoh-tokoh melalui tingkah lakunya dengan tokoh lain.

Salah satu novel fiksi yang diadaptasi dari kisah nyata tokoh pemeran utama adalah Novel Faith and The City karya Hanum Salsabiela Rais dan Rangga Almahendra. Novel ini merupakan sebuah produk karya sastra yang masuk dalam kategori novel drama kehidupan keluarga. Selain itu juga memiliki pesan moral, religius yang tinggi, dan terkandung juga nilainilai pendidikan karakter di dalamnya. Setelah sebelumnya ada novel karya Hanum Salsabiela Rais dan Rangga Almahendra dengan judul 99 Cahaya di Langit Eropa dan novel Bulan Terbelah di Langit Amerika yang juga menjadi novel terlaris beberapa tahun sebelumnya.

\footnotetext{
${ }^{1}$ Burhan. Nurgiyantoro, Teori Pengkajian Fiksi (Yogyakarta: Gadjah Mada University Press., 2013).

${ }^{2}$ Rahmat Djoko Pradopo, Prinsip-Prinsip Kritik Sastra Teori Dan Penerapannya. (Yogyakarta: Gadjah Mada University Press., n.d.).

${ }^{3}$ Endang Rahmawati and Achsani Ferdian, "Nilai-Nilai Moral Novel Peter Karya Risa Saraswati Dan Relevansinya Dengan Pembelajaran Bahasa," Lingua Franca: Jurnal Bahasa, Sastra, Dan Pengajarannya 7 , no. 1 (2019): 52-64.
} 
Setelah kedua novel di atas maka hadirlah novel Faith and The City ini merupakan salah satu novel best seller karya Hanum Salsabiela Rais dan Rangga Almahendra.

Novel Faith and The City juga sudah diadaptasi menjadi sebuah film dengan judul Hanum dan Rangga yang telah tayang pada awal bulan november lalu. Maka dari itu peneliti memiliki alasan untuk menjadikan novel Faith and The City sebagai objek penelitiannya, karena novel ini merupakan novel karya populer dari seorang pengarang terkenal di Indonesia. Novel ini menggambarkan sebuah kehidupan keluarga pasangan suami istri yang penuh perjuangan untuk hidup di negara orang dan banyak cobaan yang harus mereka lewati. Novel ini merepresentasikan kehidupan nyata masyarakat yang tinggal jauh dari Indonesia dan harus berjuang dalam mempertahankan kekuatan iman serta keyakinan yang baik dalam karakternya.

Sedikit gambaran dari novel Faith and The City adalah sebuah potret kehidupan pasangan Hanum Salsabiela Rais dan Rangga Almahendra saat meraka tinggal di New York Amerika Serikat. Cerita pada novel Faith and The City berawal ketika Hanum dan Rangga yang hendak meninggalkan Kota New York setelah mereka menyelesaikan tugasnya masingmasing. Mereka akan kembali ke Wina Austria, untuk mengukir lembaran baru kehidupan keluarga mereka dengan saling mendukung dalam karier dan profesi, meski keturunan belum hadir di tengah mereka.

Sarana penanaman nilai-nilai pendidikan karakter pada akhir-akhir ini bisa diangkat dari sebuah novel. Salah satu novel yang dapat diangkat pesannya adalah novel Faith and The City karya Hanum Salsabiela Rais dan Rangga Almahendra. Peneliti berpendapat bahwa novel ini wajib dibaca oleh kalangan remaja hingga dewasa karena dalam novel ini terdapat nilainilai pendidikan karakter, nilai religius, serta nilai moral yang patut untuk diteladani dan dipraktikkan pada kehidupan sehari-hari setelah pembaca selesai membaca novel ini. Dengan penanaman nilai-nilai pendidikan karakter pada pembaca akan menumbuhkan rasa simpati ataupun empati dalam diri seseorang dan terhadap orang lain. Tak hanya itu, melalui cerita dalam karya sastra novel diharapkan dapat dijadikan teladan dalam kehidupan sehari-hari ${ }^{4}$.

Novel Faith And The City Karya Hanum Salsabiela Rais dan Rangga Almahendra yang fenomenal pada tahun 2018 memunculkan berbagai tanggapan dari para pembaca. Setelah novel ini diadaptasi oleh sebuah rumah produksi menjadi sebuah film layar lebar bertajuk Hanum dan Rangga, maka tanggapan dari para pembaca semakin beragam dan mengapresiasi novel tersebut. Dapat diketahui bahwa setiap pembaca dengan pembaca yang lainnya pasti akan

\footnotetext{
${ }^{4}$ Farida Yufarlina Rosita and Achsani Ferdian, "Pendidikan Karakter Dalam Novel Cinta 2 Kodi Karya Asma Nadia," Alayasastra 14, no. 1 (2018): 55-71.
} 
berbeda dalam menanggapi sebuah karya sastra. Tanggapan itu bisa bernilai positif maupun negatif, bergantung dari resepsi masing-masing pembaca.

Untuk mengetahui berbagai tanggapan yang muncul mengenai Novel Faith And The City Karya Hanum Salsabiela Rais dan Rangga Almahendra maka diperlukan penelitian tentang resepsi pembaca. Penelitian ini memilih guru bahasa Indonesia, mahasiswa Program Studi Tadris Bahasa Indonesia IAIN Surakarta, serta masyarakat umum sebagai subjek penelitian karena dari informan tersebut merupakan kumpulan dari sebuah masyarakat yang menyukai karya sastra. Setelah adanya uraian di atas, maka karya sastra memang memiliki hubungan erat dengan masyarakat dan pembacanya. Tanpa adanya pembaca sebuah karya sastra pasti tidak ada artinya.

Dapat disimpulkan bahwa, peneliti akan mengambil sampel dari pendapat pembaca tentang novel Faith and The City. Peneliti memilih guru bahasa Indonesia, mahasiswa Program Studi Tadris Bahasa Indonesia IAIN Surakarta yang merupakan pecinta sastra, serta masyarakat umum untuk dapat mewakili tanggapan masyarakat terhadap novel Faith And The City serta ajaran yang terkandung di dalamnya. Peneliti memilih mahasiswa Tadris Bahasa Indonesia karena selain dari segi pengetahuan mereka lebih memahami dunia sastra dibanding dengan mahasiswa program studi lainnya.

Penelitian ini bertujuan untuk mendeskripsikan dan mengeksplanasikan. Resepsi sastra pembaca mengenai novel Faith and The City karya Hanum Salsabiela Rais dan Rangga Almahendra dan nilai-nilai pendidikan karakter yang terdapat dalam novel Faith and The City karya Hanum Salsabiela Rais dan Rangga Almahendra.

\section{METODE PENELITIAN}

Penelitian ini merupakan penelitian studi pustaka dengan menggunakan pendekatan deskriptif kualitatif. Penelitian ini objek utamanya adalah novel Faith and The City karya Hanum Salsabiela Rais dan Rangga Almahendra. Novel Faith and The City dianalisis dengan kajian resepsi sastra dan menjelaskan teks-teks dalam novel yang mengandung nilai-nilai pendidikan karakter. Jadi penelitian ini tidak terlalu terpancang pada tempat penelitian, tetapi terdapat beberapa tempat yang menjadi pendukung studi pustaka yaitu perpustakaan untuk mendapatkan sumber data dan referensi.

Penelitian ini menggunakan sumber data yang berupa kutipan kata dan kalimat yang terdapat dalam novel Faith and The City karya Hanum Salsabiela Rais dan Rangga Almahendra yang diterbitkan oleh PT Gramedia Pustaka Utama, dengan tebal 227 halaman, diterbitkan dengan cetakan kedua (edisi revisi) pada tahun 2018, ISBN: 978-602-06-1863-0. Teknik 
pengumpulan data yang digunakan dalam penelitian ini adalah teknik analisis isi dokumen dan teknik wawancara.

Triangulasi merupakan teknik pemeriksaan keabsahan data yang berfungsi sebagai pembanding atau mengecek terhadap data yang dimanfaatkan sesuatu yang lain dari data itu. triangulasi teori merupakan fakta yang tidak dapat diperiksa derajat kepercayaannya dengan satu atau lebib teori. ${ }^{5}$ Peneliti menggunakan berbagai teknik pengumpulan data (analisis isi dokumen yang mendalam) dan menggunakan teori kajian resepsi sastra dan nilai-nilai pendidikan karakter. Oleh karena itu dalam penelitian ini menggunakan triangulasi metode dan teori.

Teknik analisis data yang digunakan dalam penelitian ini adalah dengan menggunakan pendekatan kajian resepsi sastra pembaca. Teknik analisis data merupakan penguraian data hingga menghasilkan kesimpulan dari sebuah penelitian. Metode analisis data yang dilakukan untuk menganalisis pembahasan ini adalah metode analisis kualitatif.

\section{HASIL DAN PEMBAHASAN}

\section{Resepsi Pembaca Novel Faith and The City karya Hanum Salsabiela Rais dan Rangga}

\section{Almahendra}

Resepsi pembaca yang menyertai novel Faith and The City karya Hanum Salsabiela Rais dan Rangga Almahendra antara lain adalah Ferdian Achsani, Aulia Normalita, Yuyun Astyarini, Jamaluddin Ahmad, dan Ana Saifah Iqomatul Haq. Dari beberapa tanggapan yang telah dikemukakan oleh pembaca novel Faith and The City karya Hanum Salsabiela Rais dan Rangga Almahendra mayoritas mereka beranggapan yang hampir sama yaitu pada saat mereka membaca novel itu menggambarkan tentang konflik dalam kehidupan rumah tangga yang dijalani oleh Hanum dan Rangga sebagai tokoh utama dalam novel.

Dari berbagai pendapat yang dikemukakan oleh para pembaca tersebut memberikan bukti yang kuat mengenai novel Faith and The City adalah novel yang bagus untuk dibaca. Kemudian kekaguman juga diungkapkan oleh pembaca dengan nilai-nilai pendidikan karakter yang dapat diambil setelah membaca novel ini serta keberadaan novel Faith and The City dapat diterima dengan baik oleh semua kalangan.

Dalam penelitian ini peneliti menggunakan informan sebanyak lima informan. Kelima informan tersebut terdiri dari tiga kategori pembaca dalam resepsi sastra, yaitu: pembaca biasa; pembaca ideal; dan pembaca eksplisit. Dari berbagai resepsi pembaca tersebut diharapkan

\footnotetext{
${ }^{5}$ Lexi J. Moleong, Metode Penelitian Kualitatif. (Bandung: PT Remaja Rosdakarya Offset., n.d.).
} 
dapat mewakili pembaca secara keseluruhan dan menjadi bukti bahwa keberadaan novel Faith and The City karya Hanum Salsabiela Rais dan Rangga Almahendra dapat diterima dengan baik.

\section{a. Pembaca Biasa}

Pembaca biasa yang diwakili oleh mahasiswa Program Studi Tadris Bahasa Indonesia, Fakultas Adab dan Bahasa, IAIN Surakarta yang bernama Ferdian Achsani dan Aulia Normalita. Menurut mereka tema dari novel Faith and The City karya Hanum Salsabiela Rais dan Rangga Almahendra adalah tentang kesetiaan dan kepercayaan dalam sebuah rumah tangga. Kemudian jalan ceritanya dikemas sangat baik dan tidak membosankan untuk dibaca meskipun telah dibaca berkali-kali karena latar cerita dari novel ini berada di Kota New York Amerika Serikat yang merupakan kota impian semua orang. Menurut pembaca biasa gambaran cerita yang ditampilkan dalam novel ini unik, menarik, dan belum pernah ditemui pada novel-novel yang lain.

Berdasarkan hasil wawancara yang dikemukakan oleh pembaca biasa novel Faith and The City mengajarkan kepada pembaca, juga kepada masyarakat bahwa kekuatan sebuah hubungan adalah kepercayaan adalah harga utama dalam menjalin sebuah hubungan. Nilai-nilai pendidikan karakter dalam novel ini sangat bisa diambil pelajarannya, misal seperti ini kita dalam memahami suatu agama orang-orang Barat mengira agama Islam adalah teroris bagi mereka, tapi sebetulnya agama Islam adalah agama perdamaian. Kemudian nilai-nilai pendidikan karakter yang pertama ada sopan santun dibuktikan dari tokoh Hanum, toleransi dibuktikan pada tokoh Rangga yang memberikan kebebasan atau kelonggaran pada Hanum untuk mewujudkan cita-citanya menjadi jurnalis di New York, nilai agama yang diungkapkan oleh Azzima Hussein bahwa agama Islam adalah agama yang damai bukan agama yang radikal atau teroris.

b. Pembaca Ideal

Pembaca ideal ini diwakili oleh guru bahasa Indonesia dari dua sekolah yang berbeda. Guru bahasa Indonesia yang pertama adalah ibu Yuyun Astyarini, S.Pd yaitu guru bahasa Indonesia di Madrasah Aliyah Negeri 2 Surakarta dan guru bahasa Indonesia yang kedua adalah bapak Jamaluddin Ahmad, M.Pd. yaitu guru bahasa Indonesia di SMP Muhammadiyah 10 Surakarta. Menurut pembaca ideal ada banyak nilai-nilai pendidikan karakter yang dapat dipetik dari novel Faith and The City karya Hanum Salsabiela Rais dan Rangga Almahendra.

Menurut pendapat pembaca ideal, tokoh yang paling berkesan dan menarik dalam novel ini adalah Hanum dan Rangga sebagai tokoh utama. Dalam cerita pada novel ini, 
dari tokoh Hanum dan Rangga timbul konflik batin antara mereka berdua sebagai pasangan suami istri. Kemudian konflik batin dari Hanum ketika Hanum memiliki citacita sebagai jurnalis di Amerika, Rangga pun bersikap bijaksana untuk mengizinkan istrinya untuk mengejar cita-citanya tersebut. Jadi konflik batin yang dialami Rangga adalah dia harus berkorban demi istrinya Hanum untuk mengambil kesempatan magang di GNTV sebagai wujud rasa sayang dan cintanya pada Hanum. Walaupun sebetulnya seorang istri tidak memiliki kewajiban mencari nafkah.

Dalam novel tersebut dapat dicontohkan dari tokoh Rangga sebagai orang Indonesia yang memiliki prestasi tinggi dan mendapatkan beasiswa untuk melanjutkan kuliah sampai S3 di Wina Austria. Kemudian dicontohkan dari tokoh Hanum sebagai orang Indonesia dan seorang wanita pula, ia mampu mengejar cita-citanya yang tinggi sebagai jurnalis di Amerika Serikat. Dapat diteladani dari kedua tokoh utama dalam novel Faith and The City tersebut tentang sikap cinta tanah air dan sikap optimis yang tinggi untuk mengejar cita-cita yang dimiliki.

Dari pendapat pembaca ideal tersebut, perlu diketahui bahwa dalam novel Faith and The City banyak pembelajaran positif dalam kehidupan dan bisa ditanamkan kepada siswa sejak duduk di bangku sekolah sampai perguruan tinggi.

c. Pembaca Eksplisit

Peneliti juga melakukan wawancara kepada pembaca eksplisit diwakili oleh Ana Saifah Iqomatul Haq, S.Pd. sebagai masyarakat umum yang membaca novel Faith and The City karya Hanum Salsabiela Rais dan Rangga Almahendra. Dari sepuluh pertanyaan yang diajukan, peneliti merasa puas dengan seluruh jawaban yang disampaikan oleh informan. Menurut Ana, secara keseluruhan unsur cerita novel Faith and The City cukup baik dan menarik untuk dibaca. Oleh karena itu, perilaku positif seperti yang dicontohkan oleh tokoh dalam penggalan novel itu patut dijadikan contoh dalam kehidupan keluarga dan bermasyarakat.

Menurut pembaca eksplisit, amanat yang ingin disampaikan dari novel Faith and The City adalah kita sebagai umat Islam yang memahami bahwa ketetapan Allah adalah yang terbaik, maka seyogyanya kita tetap meyakini bahwa takdir dari Allah adalah yang terbaik. Tidak ada larangan wanita bekerja selama itu tidak melalaikan kewajibannya sebagai seorang istri.

Dari pendapat masing-masing kategori pembaca di atas maka peneliti memberikan tanggapan dan kesimpulan tentang novel Faith and The City karya Hanum Salsabiela Rais dan Rangga Almahendra sebagai berikut: 
1) Pengarang novel Faith and The City menceritakan cerita dalam novel berdasarkan kisah nyata yang dialami pengarang yaitu Hanum dan Rangga saat hidup di New York Amerika Serikat.

2) Tokoh utama Hanum Salsabiela Rais sebagai istri bekerja sebagai seorang jurnalis dan Rangga Almahendra sebagai suami sedang menyelesaikan studi S3 di Wina Austria.

3) Tema dari novel Faith and The City karya Hanum Salsabiela Rais dan Rangga Almahendra adalah tentang kesetiaan dan kepercayaan dalam sebuah rumah tangga.

4) Tokoh Hanum dan Rangga adalah tokoh utama dalam novel Faith and The City yang sangat berkesan bagi pembaca dan menarik karena dari mereka timbul konflik yang menghidupkan dari awal hingga akhir cerita.

5) Novel Faith and The City karya Hanum Salsabiela Rais dan Rangga Almahendra mengandung nilai-nilai pendidikan karakter yang dapat diterapkan dalam kehidupan sehari-hari bagi pembacanya.

6) Novel Faith and The City karya Hanum Salsabiela Rais dan Rangga Almahendra layak dibaca oleh semua kalangan pembaca dan banyak pelajaran positif yang dapat diambil oleh pembaca.

\section{Nilai-nilai Pendidikan Karakter dalam Novel Faith and The City karya Hanum Salsabiela}

\section{Rais dan Rangga Almahendra}

Selain resepsi pembaca di atas, novel Faith and The City karya Hanum Salsabiela Rais dan Rangga Almahendra mengandung nilai-nilai pendidikan karakter yang dapat diambil pelajaran oleh pembaca. Adapun nilai-nilai pendidikan karakter tersebut sebagi berikut: pengetahuan moral (kesadaran moral, pengetahuan nilai moral, penentuan perspektif, pemikiran moral, pengambilan keputusan, pengetahuan pribadi); perasaan moral (harga diri, empati, mencintai hal yang baik, kendali diri, kerendahan hati); tindakan moral (kompetensi, keinginan, kebiasaan).

Novel Faith and The City menceritakan tentang tokoh utama, Hanum dan Rangga yang sedang berada di New York Amerika Serikat dan berhasil menerapkan nilai-nilai pendidikan karakter di sana. Kedua tokoh utama tersebut menerapkan nilai-nilai tentang toleransi, kejujuran, mencintai hal baik, rendah hati, dalam kehidupan mereka sehari-hari. Dalam penelitian ini, nilai-nilai pendidikan karakter yang ada dalam novel Faith and The City dijelaskan berdasarkan teori yang dikemukakan oleh Thomas Lickona yang membagi pendidikan karakter menjadi tiga komponen karakter yang baiksebagai berikut: 


\section{a. Pengetahuan Moral}

1) Kesadaran Moral

Kesadaran moral termasuk dalam nilai pendidikan karakter yang merupakan sikap untuk menghadapi suatu masalah yang dihadapi. Kesadaran moral ini dimaksudkan agar seseorang bisa tanggap dalam menghadapi persoalan yang terjadi dalam kehidupan. Novel Faith and The City karya Hanum Salsabiela Rais dan Rangga Almahendra bercerita tentang kehidupan pasangan Hanum dan Rangga yang sedang menjalani kehidupan di Kota New York Amerika Serikat. Terjadi banyak permasalahan dalam kehidupan keluarga mereka, dari rencana awal mereka berdua akan kembali ke Wina, Austria untuk mengukir lembaran hidup baru sebagai suami istri yang saling mendukung dalam karier dan profesi.

Seperti kisah Hanum dan Rangga yang memiliki permasalahan dalam kehidupan rumah tangga mereka, tetapi mereka mampu menyelesaikannya dengan baik. Memang dalam menjalani kehidupan pasti akan terjadi banyak permasalahan yang dihadapi, tetapi kita sebagai manusia harus mampu mengatasi permasalahan tersebut. Pengarang mengajak pembaca agar mampu mengatasi masalah yang dihadapi dalam kehidupan ini dengan baik dan benar.

2) Mengetahui Nilai Moral

Komponen pendidikan karakter berikutnya adalah mengetahui nilai moral seperti menghargai kehidupan seseorang, bertanggung jawab terhadap orang lain, kejujuran, keadilan, toleransi, disiplin diri, rasa hormat, dan sebagainya. Untuk mengetahui nilai moral dapat dilihat dari kegiatan sehari-hari yang dilakukan oleh seseorang.

Mengetahui nilai moral yang terdapat dalam novel Faith and The City karya Hanum Salsabiela Rais dan Rangga Almahendra adalah sikap disiplin, toleransi, dan rasa hormat. Sikap disiplin merupakan sikap patuh, taat, dan memiliki tekad. Sikap rasa hormat adalah sikap saling menghargai satu sama lain dalam kehidupan.

Pada novel Faith and The City sikap disiplin ditunjukkan oleh Hanum yang memiliki tekad kuat untuk mewujudkan cita-citanya menjadi seorang jurnalis terkenal di New York City, tetapi dia juga menyadari kewajibannya sebagai seorang istri untuk selalu patuh dan berbakti pada suaminya Rangga. Maka itu Hanum akan menuruti kemauan Rangga untuk menemaninya melanjutkan studi S2 di Wina. Hanum akan melakukan apa saja untuk kebahagiaan hidup rumah tangganya bersama Rangga. Dari sikap hanum tersebut juga menunjukkan bahwa ia memiliki rasa hormat pada suaminya Rangga. Disiplin adalah sikap yang harus dilakukan oleh manusia dalam menjalankan 
kehidupan. Dengan sikap disiplin yang dimiliki maka seseorang akan teratur dan tertata dalam menjalankan hidupnya.

Kemudian mengetahui nilai moral berikutnya adalah sikap toleransi. Toleransi merupakan sikap menerima dan mengalah pada suatu keadaan agar tidak terjadi perselisihan. Sikap toleransi ini ditunjukkan oleh tokoh Rangga yang memberikan kesempatan pada Hanum untuk mengambil kesempatan yang ditawarkan Cooper untuk mengikuti magang tiga minggu di GNTV. Sikap toleransi sangat dibutuhkan oleh manusia agar manusia saling menghargai satu sama lain dan tidak memiliki sikap sombong. Jika seseorang tidak memiliki sikap toleransi maka akan menimbulkan perselisihan karena satu sama lain tidak mau mengalah dan mau menangnya sendiri dan tidak mau mempertanggungjawabkan suatu kesalahan.

3) Penentuan Perspektif

Penentuan perspektif merupakan penentuan diri dalam menghadapi masalah serta tindakan apa yang akan dilakukan untuk menghadapi masalah tersebut. Sikap ini ditunjukkan oleh Rangga yang sangat membutuhkan Hanum untuk membantunya menyelesaikan disertasi di Wina. Karena dengan adanya Hanum di samping Rangga maka ia akan cepat menyelesaikan disertasi dan lulus dari studi S3-nya. Hanum juga mau untuk membantu dan menemani Rangga kembali ke Wina.

4) Pemikiran Moral

Pemikiran moral merupakan berpikir mengenai baik atau buruknya perilaku yang dilakukan dalam kehidupan. Dengan adanya pemikiran moral maka sikap baik ataupun buruk dapat dipilah sesuai situsi dan kondisi yang sedang dialami. Pemikiran moral ini dibuktikan dengan permintaan Cooper kepada Hanum untuk bekerja di stasiun televisi yang dipimpinnya yaitu GNTV. Cooper terdorong oleh kesuksesan Hanum sebagai wartawan yang sangat cerdas dan cerdik dalam mencari berita dari narasumber. Dari kesuksesan Hanum itulah yang termasuk pemikiran moral karena tahu mana baik dan buruknya kehidupan.

Kemudian pemikiran moral berikutnya dibuktikan dari Hanum yang memiliki sikap percaya diri dengan kesempatan yang telah diberikan Cooper kepadanya untuk memegang program di GNTV. Oleh karena itu, Hanum akan membuktikan bahwa dirinya bisa membuat grafik-grafik ratting danshare acaranya meningkat drastis. Orang yang memiliki pemikiran moral yang baik maka akan selalu bersikap optimis dan jujur dalam menjalankan kehidupan. 
5) Pengambilan Keputusan

Pengambilan keputusan merupakan langkah untuk memilih tindakan yang akan dilakukan untuk menyelesaikan permasalahan. Dengan pengambilan keputusan juga akan diketahui konsekuensi atas apa pilihan yang sudah dipilih. Pengambilan keputusan adalah bagian dari pengetahuan yang harus dimiliki seseorang untuk mengambil suatu keputusan dalam hidupnya. Sikap pengambilan keputusan ini dibuktikan pada sikap Hanum ketika mengambil keputusan untuk melupakan traumanya menjadi penulis artikel medioker.

Hanum akan membuktikan bahwa dirinya bisa menjadi wartawan terkenal dan hebat setelah bekerja di GNTV New York, agar bos-bosnya yang dulu sempat meremehkan dirinya bisa tahu bahwa Hanum bisa sukses. Hanum berjanji kepada Rangga untuk percaya pada kata-katanya bahwa Hanum mampu untuk mewujudkan impiannya sebagai wartawan sukses setelah bekerja di GNTV. Dengan keputusan itu akhirnya Rangga luluh dan mau menemani Hanum di New York dua minggu magang di GNTV.

6) Pengetahuan Pribadi

Rasa pengetahuan pribadi dalam novel Faith and The City karya Hanum Salsabiela Rais dan Rangga Almahendra adalah sikap pengenalan terhadap diri sendiri untuk dapat memahami apa kekurangan dan kelebihan setiap orang memang berbeda, serta cara menyelesaikan permasalahan pun juga berbeda-beda setiap pribadinya. Bentuk rasa pengetahuan pribadi dibuktikan dari tokoh Rangga yang menyadari bahwa ia sebagai seorang pria dan suami difitrahkan untuk takluk pada wanita. Rangga merasa bahwa ia harus menuruti apa keinginan istrinya apalagi keinginan baik untuk kemajuan karier istrinya.

Pengetahuan pribadi yang terdapat dalam penggalan novel Faith and The City karya Hanum Salsabiela Rais dan Rangga Almahendra membuktikan adanya bentuk rasa saling memahami kekurangan dan kelebihan antar pasangan dalam rumah tangga Hanum dan Rangga agar semakin erat.Berdasarkan hal tersebut, dapat diketahui bahwa pengetahuan pribadi terhadap pasangan dapat tercipta kepada siapapun. Karena dengan berbuat baik dan mengerti antar pasangan dapat merasakan kedamaian dan ketentraman dalam rumah tangga.

\section{b. Perasaan Moral}

1) Hati Nurani

Sikap atau rasa bersalah yang membangun merupakan tindakan dari hati nurani manusia.Hati nurani merupakan perasaan moral yang berkaitan dengan kesadaran seseorang untuk memiliki rasa bersalah dan memperbaiki kesalahan yang dilakukan. Hal 
ini dilakukan agar tidak terjadi salah paham ataupun dendam yang seseorang kepada orang lain. Tindakan hati nurani memiliki komitmen untuk menghidupi nilai moral mereka yang berakar pada nilai-nilai pendidikan karakter pada seseorang.

Bentuk hati nurani dalam penggalan novel Faith and The City karya Hanum Salsabiela dan Rangga Almahendra adalah saat pertemuan pertama antara Rangga dengan Hanum tanpa sengaja saat mereka sama-sama sedang berada di masjid yang sama. Hanum adalah seorang wanita yang haram untuk keluar malam apalagi pergi dengan seorang pria karena didikan orang tuanya sejak kecil tentang agama yang sangat kuat.Dengan dimilikinya hati nurani pada setiap manusia akan terbentuk nilai-nilai pendidikan karakter yang membangun kehidupan.

2) Harga Diri

Harga diri merupakan sikap memiliki percaya diri di hadapan orang lain. Sikap pengembangan harga diri ini berkaitan erat dengan sikap jujur, tanggung jawab, dan keyakinan pada diri sendiri (optimis) pada kemampuan diri.

Wujud harga diri dibuktikan dalam penggalan novel Faith and The City melalui rasa percaya diri yang ditunjukkan Hanum sangat besar dan pada akhirnya ketika Hanum dan Rangga masih tinggal di Wina, tiba-tiba Heute ist Wunderbar tertarik dengan CVnya. Pada akhirnya Hanum diterima bekerja di sana untuk menjadi wartawan medioker. Itu membuat Hanum puas dan percaya diri dengan dirinya.

Berdasarkan hal tersebut, membuktikan bahwa harga diri harus dimiliki setiap manusia agar selalu bersikap optimis pada kemampuan diri sendiri. Setiap manusia yang memiliki harga diri pasti ia akan bersikap jujur serta tanggung jawab dalam setiap masalah kehidupan.

3) Empati

Rasa empati merupakan sikapsolodaritas tinggi pada diri orang lain. Empati berasal dari sikap seseorang yang merasa seolah-olah merasakan pengalaman yang terjadi pada orang lain itu menimpa kepada dirinya.

Bentuk rasa empati dalam novel Faith and The City karya Hanum Salsabiela Rais dan Rangga Almahendra ditunjukkan dari sikap Cooper kepada Azima Hussein. Cooper menghentikan mobilnya saat melihat Azima dipinggir jalan sedang kebingungan karena mobilnya mogok. Kemudian Cooper memberikan kartu namanya pada Azima setelah ia membantu memperbaiki mobil Azima. Hati Cooper tergerak membantu Azima karena Azima telah menginspirasi jutaan orang karena ia adalah wanita yang memiliki keteguhan hati. 
Hal tersebut menunjukkan sisi rasa empati yang dilakukan tanpa pamrih apapun. Dapat diketahui bahwa empati terhadap sesama manusia dapat tercipta dimana pun dan kapan puntanpa mengenal agama, ras, budaya, dan lain sebagainya. Maka dengan berbuat baik maka semua manusia akan merasakan kedamaian dalam hidup di masyarakat umum.

4) Mencintai Hal yang Baik

Wujud mencintai hal yang baik adalah ketika seseorang memiliki kesan baik terhadap sesuatu, biasanya ia akan memiliki rasa cinta terhadap hal yang baik yang telah dialami. Seseorang yang mencintai hal baik biasanya memiliki keinginan untuk menjadi penolong agar orang lain tidak merasa kesulitan.

Rasa mencintai hal yang baik ini dibuktikan oleh tokoh Hanum yang merupakan seorang istri yang setia pada suaminya Rangga. Selama tiga tahun ia mengabdi pada suaminya saat masih berada di Wina. Hanum rela meninggalkan pekerjaan yang dicintainya di Indonesia demi untuk menemani suaminya melanjutkan studi S3 nya di Wina Austria. Tetapi Hanum menikmati itu semua karena ia sangat mencintai Rangga.

Kemudian Hanum Salsabiela Rais dalam novelnya menuliskan contoh perbuatan mencintai hal baik dari tokoh Rangga seorang suami yang sangat mencintai istrinya Hanum dan merasa tidak ada perempuan lain yang lebih baik daripada Hanum di dalam kehidupannya.

5) Kendali Diri.

Kendali diri merupakan sikap membatasi diri sendiri terhadap suatu tindakan.Sikap ini terdapat dalam novel Faith and The City karya Hanum Salsabiela Rais dan Rangga Almahendra. Bentuk sikap kendali diri sangat diperlukan untuk menahan diri agar tidak selalu memanjakan diri sendiri terhadap sesuatu yang diinginkan.

Bentuk sikap kendali diri ditunjukkan oleh tokoh Hanum dan Rangga yang sudah menundukkan kota New York. Walaupun kota New York adalah kota yang menggoda, merayu, dan penghuninya. Tetapi dengan cinta dan keyakinan Hanum dan Rangga akan Tuhan mampu mempertemukan mereka dalam ikrar suci kembali. Sikap yang dicontohkan oleh Hanum dan Rangga merupakan bentuk kendali diri yang dilakukan Hanum dan Rangga agar tidak tergoda dan tunduk pada New York yang memiliki ribuan pesona.

Selain itu sikap kendali diri dibuktikan dalam novel Faith and The City ketika Hanum bekerja menjadi jurnalis di Wina dan menjadi anak buah yang bandel tetapi selalu dirindukan oleh bosnya Gertrude. Walaupun begitu Hanum menyukainya dan tiba-tiba 
Cooper melamarnya untuk menjadi jurnalis di GNTV. Hanum merasa dirinya wartawan nyamuk yang naik kelas dan diminati seluruh dunia.

6) Kerendahan Hati.

Rasa kerendahan hati merupakan sikap yang dapat membantu dalam mengatasi kesombongan agar tidak merasa besar kepala. Rasa kerendahan hati ditunjukkan oleh tokoh Hanum yang diberi bingkisan perpisahan dari Layla putri angkat Philipus Brown.

Hanum merasa bingkisan yang diberikan Layla padanya sangat berlebihan. Bingkisan perpisahan berisi jam tangan indah dan berkelas. Hanum merasa pemberian jam tangan itu sangat berlebihan tetapi dengan kerendahan hati yang dimiliki Hanum, ia mengucapkan terima kasih dan tetap menghargai apa yang telah diberikan Layla kepadanya.

Novel Faith and The City memberikan bukti bahwa dengan memiliki sikap rendah hati akan menghindarkan dari sifat sombong. Sikap rendah hati harus dimiliki oleh setiap manusia karena ini merupakan persaan moral yang baik dan harus ada pada diri seseorang.

\section{c. Tindakan Moral}

1) Kompetensi

Kompetensi merupakan sikap yang berupa kewenangan untuk menentukan atau memutuskan sesuatu hal. Kompetensi merupakan tindakan moral yang berperan dalam situasi tertentu. Sikap kompetensi yang terungkap dalam novel karya Hanum Salsabiela Rais dan Rangga Almahendra ini dapat digunakan sebagai pemecah suatu konflik yang terjadi agar segera terselesaikan.

Melalui kompetensi yang dimiliki Hanum dapat membuat Cooper memberikan tawaran kepada Hanum untuk menjadi produser andal dan memiliki ide segar di GNTV. Hanum memiliki kompetensi seperti yang telah dilakukannya pada acara Brown kemarin, ia adalah wartawan yang sangat gigih. Hal tersebut menunjukkan sisi kompetensi yang dilakukan untuk membuktikan bahwa seseorang itu mampu dan bisa membuktikan kempuan dan kelebihan yang dimiliki.

Berikutnya kompetensi dibuktikan bahwa Hanum adalah seseorang yang ambisius untuk mengejar kesempatan yang ia miliki. Dengan rasa kompetensi yang dimiliki akan membuat seseorang memiliki rasa percaya diri dan akan membuktikan bahwa dirinya bisa melakukan apa yang diyakini bisa dengan kemampuan tersebut. 
2) Keinginan

Rasa keinginan digunakan untuk menjaga emosi di bawah kendali pemikiran. Keinginan merupakan hasrat untuk membatasi atau menolak emosi, melawan gelombang harapan. Selain itu, keinginan dapat digunakan untuk menghadapi permasalahan dan bagaimana penyelesaiannya. Keinginan menuntut seseorang untuk melakukan tindakan nyata dalam kehidupannya.

Dibuktikan dalam novel Faith and The City ketika Hanum meminta suaminya agar mau menemani dirinya untuk mengambil magang jurnalis selama 3 minggu di GNTV New York. Keinginan yang dimiliki Hanum ini merupakan suatu harapan untuk mencapai cita-cita yang telah Hanum inginkan sejak lama.

Berdasarkan hal tersebut, dapat diketahui bahwa suatu keinginan yang dimiliki seseorang merupakan tekad besar agar dapat dicapai. Dengan keinginan seseorang mampu mencapai cita-citanya setinggi mungkin dan mampu membuktikan bahwa dirinya bisa mewujudkan keinginan tersebut.

3) Kebiasaan

Kebiasaan merupakan pelaksanaan tindakan moral yang dapat dikembangkan. Kebiasaan dalam tindakan moral merupakan karakter yang baik dalam menentukan pilihan secara tidak sadar dalam melakukan sesuatu karena itu sudah biasa ada pada diri seseorang. Seseorang yang memiliki kebiasaan baik pasti akan menjaganya agar selalu melakukan kebaikan dalam setiap kegiatannya. Tetapi kebalikannya jika seseorang memiliki kebiasaan buruk maka kebiasaan tersebut sebaiknya harus dihilangkan agar tidak membawa pada keburukan.

Dicontohkan dalam novel Faith and The City bahwa Hanum merupakan perempuan satu-satunya yang berhijab. Hanum adalah seorang muslim yang taat maka dari itu ia memiliki kewajiban untuk menggunakan hijab dan itu sudah menjadi kebiasaannya setiap hari. Kemudian Hanum terbiasa berdoa terlebih dahulu sebelum bertemu dengan Cooper. Dengan berdoa Hanum merasa tenang dan siap untuk bertemu Cooper untuk menyampaikan permintaan maafnya yang menyentuh hati. Kebiasaan doa ini adalah kebiasaan yang baik dan merupakan pelaksaan tindakan moral yang dapat dikembangkan. Kebiasaan ini merupakan pelaksanaan tindakan moral yang dapat dikembangkan. Karena seseorang yang memiliki kebiasaan baik pasti akan menjaganya agar selalu melakukan kebaikan. 


\section{KESIMPULAN}

Resepsi sastra dalam novel Faith and The City karya Hanum Salsabiela Rais dan Rangga Almahendra ini telah peneliti pilih menjadi tiga kategori menurut Umar Junus yaitu pembaca biasa, pembaca ideal, dan pembaca eksplisit. Pada dasarnya ketiga kategori pembaca tersebut, memiliki persepsi yang tidak jauh berbeda, yaitu mereka sepakat bahwa novel Faith and The City karya Hanum Salsabiela Rais dan Rangga Almahendra merupakan novel yang ditulis berdasarkan cerita pengalaman hidup Hanum dan Rangga selama mereka di New York Amerika Serikat yang memiliki banyak konflik. Dari konflik yang terjadi dalam kehidupan rumah tangga Hanum dan Rangga akhirnya mereka dapat melewatinya dan akhirnya mereka dapat bersatu kembali. Novel Faith and The City ini merupakan novel yang sangat unik, menarik, dan representatif dibaca oleh semua kalangan. Dari pendapat pembaca selaku informan berpendapat bahwa banyak pembelajaran dan nilai-nilai pendidikan karakter yang positif dapat diambil pelajarannya bagi pembaca.

Novel Faith and The City karya Hanum Salsabiela Rais dan Rangga Almahendra mengandung nilai-nilai pendidikan karakter yang dapat diambil pelajaran oleh pembaca. Adapun nilai-nilai pendidikan karakter tersebut sebagai berikut: pengetahuan moral (kesadaran moral, mengetahui nilai moral, penentuan perspektif, pemikiran moral, pengambilan keputusan, pengetahuan pribadi); perasaan moral (harga diri, empati, mencintai hal yang baik, kendali diri, kerendahan hati); tindakan moral (kompetensi, keinginan, kebiasaan).Dari nilainilai pendidikan karakter tersebut, nilai pendidikan karakter yang paling menonjol dalam novel Faith and The City karya Hanum Salsabiela Rais dan Rangga Amahendra adalah pengetahuan moral yang berupa mengetahui nilai moral.

\section{DAFTAR PUSTAKA}

Moleong, Lexi J. Metode Penelitian Kualitatif. Bandung: PT Remaja Rosdakarya Offset., n.d. Nurgiyantoro, Burhan. Teori Pengkajian Fiksi. Yogyakarta: Gadjah Mada University Press., 2013.

Pradopo, Rahmat Djoko. Prinsip-Prinsip Kritik Sastra Teori Dan Penerapannya. Yogyakarta: Gadjah Mada University Press., n.d.

Rahmawati, Endang, and Achsani Ferdian. "Nilai-Nilai Moral Novel Peter Karya Risa Saraswati Dan Relevansinya Dengan Pembelajaran Bahasa." Lingua Franca: Jurnal Bahasa, Sastra, Dan Pengajarannya 7, no. 1 (2019): 52-64.

Rosita, Farida Yufarlina, and Achsani Ferdian. "Pendidikan Karakter Dalam Novel Cinta 2 Kodi Karya Asma Nadia." Alayasastra 14, no. 1 (2018): 55-71. 